\title{
CCL14 wt Allele
}

National Cancer Institute

\section{Source}

National Cancer Institute. CCL14 wt Allele. NCI Thesaurus. Code C49714.

Human CCL14 wild-type allele is located in the vicinity of $17 q 11.2$ and is approximately 3 $\mathrm{kb}$ in length. This allele, which encodes C-C motif chemokine 14 protein, is involved in the regulation of intracellular calcium concentration and enzyme release in monocytes. The allele also plays a role in CD34 myeloid progenitor cell proliferation. 